\title{
Characterization and Gene Expression of Vitellogenesis-Related Transcripts in the Hepatopancreas and Ovary of the Red Swamp Crayfish, Procambarus clarkii (Girard, 1852), during Reproductive Cycle
}

\author{
Chiara Manfrin ${ }^{1, *}++^{\mathbb{D}}$, Moshe Tom ${ }^{2,+}{ }^{,}$, Massimo Avian ${ }^{1}$, Silvia Battistella ${ }^{1}$, Alberto Pallavicini ${ }^{1}$ \\ and Piero Giulio Giulianini ${ }^{1}$ \\ 1 Department of Life Sciences, University of Trieste, Via Licio Giorgieri 5, 34127 Trieste, Italy; \\ avian@units.it (M.A.); battiste@units.it (S.B.); pallavic@units.it (A.P.); giulianini@units.it (P.G.G.) \\ 2 Israel Oceanographic and Limnological Research, P.O.B 9753, Haifa 3109701, Israel; tom@ocean.org.il \\ * Correspondence: cmanfrin@units.it \\ + These authors contributed equally to this work.
}

check for updates

Citation: Manfrin, C.; Tom, M.; Avian, M.; Battistella, S.; Pallavicini, A.; Giulianini, P.G. Characterization and Gene Expression of Vitellogenesis-Related Transcripts in the Hepatopancreas and Ovary of the Red Swamp Crayfish, Procambarus clarkii (Girard, 1852), during Reproductive Cycle. Diversity 2021, 13, 445. https://doi.org/10.3390/ d13090445

Academic Editors: Michael Wink and Gary H. Dickinson

Received: 9 August 2021

Accepted: 10 September 2021

Published: 16 September 2021

Publisher's Note: MDPI stays neutral with regard to jurisdictional claims in published maps and institutional affiliations.

Copyright: (C) 2021 by the authors. Licensee MDPI, Basel, Switzerland. This article is an open access article distributed under the terms and conditions of the Creative Commons Attribution (CC BY) license (https:// creativecommons.org/licenses/by/ $4.0 /)$.

\begin{abstract}
The major component of the animal egg yolk is the lipoglycoprotein vitellin, derived from its precursor vitellogenin (VTG), which is produced species-specifically in decapod crustaceans in the hepatopancreas and/or in the ovary of reproductive females. Previous studies on Procambarus clarkii vitellogenesis report the existence of two single VTGs. Here, from a multiple tissue transcriptome including ovaries and hepatopancreas of P. clarkii, we characterized four different VTG and two VTGlike transcriptomes encoding for the discoidal lipoprotein-high density lipoprotein/ $\beta$-glucan binding protein $(d L p / H D L-B G B P)$. The relative expression of the various genes was evaluated by quantitative Real-Time PCR in both the ovary and hepatopancreas of females at different reproductive stages (from immature until fully mature oocytes). These studies revealed tissue-specificity and a reproductive stage related expression for the VTGs and a constitutive expression in the hepatopancreas of $d L p / H D L-$ $B G B P$ independent from the reproductive stage. This study may lead to more detailed study of the vitellogenins, their transcription regulation, and to the determination of broader patterns of expression present in the female hepatopancreas and ovary during the vitellogenesis. These findings provide a starting point useful for two different practical aims. The first is related to studies on P. clarkii reproduction, since this species is highly appreciated on the market worldwide. The second is related to the study of new potential interference in P. clarkii reproduction to delay or inhibit the worldwide spread of this aggressively invasive species.
\end{abstract}

Keywords: Procambarus clarkii; Crustacea; Decapoda; vitellogenesis; digital gene expression analysis; discoidal lipoprotein; $\beta$-glucan binding protein

\section{Introduction}

Ovarian development is characterized by the accumulation of a major egg-yolk protein precursor, vitellogenin (VTG), that serves as a food reserve for the embryo. Since the 1970s, the formation of a lipoprotein complex or vitellogenin has been known to be a prerequisite to the constitution of the protein yolk in myriapods, crustaceans, insects, amphibians, and birds. This vitellogenin is associated with other prosthetic groups and synthetized outside the ovary, transported by the hemolymph and sequestered by the oocytes [1]. In crustaceans the development of the oocyte comprises two distinguished stages, named "primary vitellogenesis" characterized by glycoprotein granule accumulation and "secondary vitellogenesis" or vitellogenesis strictly speaking, that occurs solely during reproduction [2]. This latest phase, in crustaceans, is mainly heterosynthetic since the vitellogenin is carried in the hemolymph and sequestered by the oocytes [3]. 
The source of VTG in crustaceans has been controversial for many years. Several authors in the late 1960s suggested hemocytes as the site of VTG synthesis [4], but the two main tissues of VTG production are now globally accepted to be the ovaries as shown in Callinectes sapidus [5] and Penaeus semisulcatus [6], or the hepatopancreas, as found in Charybdis feriata [7], Macrobrachium rosenbergii [8], Oziothelphusa senex [9], and Pandalus hypsinotus [10]. In some other crustacean species, the VTG synthesis sites are both the hepatopancreas and ovary, as shown in Carcinus maenas [11], Eriocheir sinensis [12], Macrobrachium nipponense [13], Marsupenaeus japonicus [14], Penaeus monodon [15], and Scylla paramamosain [16], although the contribution of the ovary is relatively less than that of the hepatopancreas.

Another controversial question concerns the number of VTGs discovered in a single crustacean species, or rather whether one or more homologous VTGs participate together in crustacean reproduction. In the Arthropoda, there are three homologous genes that arose from ancient insect vitellogenin duplications and are known as VTG-like- $A,-B$, and $-C$ in Apis mellifera [17] and four copies in Solenopsis invicta [18]. The function of these homologous VTGs is unclear [17]. During evolution, it seemed that crustaceans reduced these genes up to two VTG copies, which have been described in a variety of species [19-29].

In the present study, we used Procambarus clarkii (Girard, 1852) as a model organism to identify and investigate the expression of VTGs and VTG-like transcripts. The red swamp crayfish, native to Mexico and the United States, is considered a ubiquitous invasive species worldwide, while representing a valuable aquaculture resource on international markets [30-32]. It is an r-selected species with a ductile life cycle that breeds year-round, with variable recruitment peaks in summer, early winter, and spring [33,34]. A constant $100 \%$ of mature males observed in the North Italy population from July to September indicates possible successful mating during this season which may extend to the end of October at these latitudes [35].

Many studies focusing on VTG and P. clarkii reproduction refer to one single VTG in this decapod species [36-39]. To investigate this aspect, a comprehensive P. clarkii transcriptome assemblage consisting of 12 different tissues was previously constructed by one of us (Manfrin communication) and used here to identify the available P. clarkii VTG transcripts and those of the high-density lipoprotein / $\beta$ glucan binding protein $(\alpha L p / H D L-$ $B G B P$, hereinafter referred to as $B G B P$ ). The later gene is responsible for transport of lipids and is also fundamental for the innate immune response of crustaceans $[40,41]$. The transcript characterization was followed by examination of their transcription patterns in the female ovary and hepatopancreas during the ovarian development period, observing their transcription level during the ovarian developmental period.

\section{Materials and Methods}

\subsection{Ethical Note}

The following experimental procedures are in accordance with current Italian law. No special permits were required for this study, as no endangered or protected species were involved. Individuals were kept under appropriate laboratory conditions to ensure their welfare and responsiveness. After completion of the experiments, the crayfish were euthanized by hypothermia.

\subsection{Transcripts Identification}

The identification of VTGs and general lipid carriers which share domains with VTG followed a similarity-based process based on the use of conserved domains, both in public repositories (i.e., NCBI) and using a comprehensive transcriptome assembly (hereafter defined as ATLAS). The ATLAS consisted of 12 different $P$. clarkii tissues, namely brain, heart, ventral ganglia, eyestalk, green gland, ovary, testis, hepatopancreas, muscle, Y-organ, gill, and hemocyte, Illumina sequenced (depth $2 \times 100 \mathrm{bp}$ ) (unpublished results). CLC Genomics Workbench v.12 (Qiagen, Hilden, Germany) was used to map the reads from each tissue to the assembly for initial identification of tissues of interest, using the RNA- 
seq analysis tool with the following parameter settings: mismatch cost 2, gap insertion and deletion cost 3 , end gaps 0 , length fraction 0.95 , similarity fraction 0.98 . The protein molecular weight was estimated by Expasy-Compute $\mathrm{pI} / \mathrm{Mw}$ and the presence of cleavage site was evaluated with SignalP 5.0.

\subsection{Comparative Studies}

The phylogeny of VTGs was inferred using the online tool NGPhylogeny.fr [42]. Briefly, the VTGs corresponding to all available complete proteins from the group "Crustacean" at GenBank, were aligned through MAFFT v.7 [43] and the alignment was curated by BMGE [44]. PhyML was used to infer the tree [45].

The ovaries of females were removed to photographically record the external morphology at various stages of development; photos were taken with an Olympus BX50.2.4.

Total RNA was extracted from tissues (ovary and hepatopancreas) frozen in liquid nitrogen using the TriReagent RNA isolation kit (Sigma-Aldrich, Saint Louis, MO, USA) according to the manufacturer's instructions. The resulting RNAs were further purified using the E.Z.N.A. ${ }^{\mathrm{TM}}$ MicroElute RNA Clean-up Kit (Omega Bio-Tek, Norcross, GA, USA). The amount of RNA was quantified spectrophotometrically using Nanodrop 2000 (Thermo Fisher Scientific, Waltham, MA, USA) and its quality was analyzed by capillary electrophoresis BioAnalyzer 2100 (Agilent, Santa Clara, CA, USA).

\subsection{Transcript Expression by $q R T-P C R$}

The relative gene expression of selected VTGs and BGBPs in P. clarkii was examined by quantitative Real-Time PCR (qRT-PCR), in both ovary and hepatopancreas of twenty females containing oocytes from the 2nd to 6th developmental stages [46]. Preparation of cDNAs was performed using M-MLV reverse transcriptase (Promega) and oligoT(18) primer starting from $1 \mu \mathrm{g}$ of total RNA and following the manufacturer's instructions. Specific primers were designed using Primer3Web version 4.0.0 [47] and Oligo Calculator version 3.26 [48] to predict possible secondary structure and hairpin formation, as shown in Table 1. A dilution of $1 / 5$ of the initial cDNA was used for qRT-PCR, which was performed in triplicate on the CFX96 Real-Time PCR detection system (Bio Rad, Hercules, CA, USA), using the following thermal profile: denaturation at $95^{\circ} \mathrm{C}$ for $1^{\prime}, 40$ cycles at $95^{\circ} \mathrm{C}$ for $15^{\prime \prime}$ and $60^{\circ} \mathrm{C}$ for $20^{\prime \prime}$ and a final melting curve analysis from $65^{\circ} \mathrm{C}$ to $95^{\circ} \mathrm{C}$ with an increment of $0.5^{\circ} \mathrm{C}$ every $5^{\prime \prime}$. The $15 \mu \mathrm{L}$ reaction mix contained the SsoAdvanced universal probes supermix (BioRad, Hercules, CA, USA), and the reverse and forward primers were used at the final concentration of $0.5 \mu \mathrm{M}$ each.

Table 1. Primer sequences used for VTGs and BGBPs qRT-PCR experiments. PcVTG1-4 amplify VTGs, PcBGBP1 and 2 amplify discoidal lipoprotein-high density- $\beta$-glucan binding transcripts. PcEF1 $\alpha$ : Elongation factor $1 \alpha$. Pc $\beta$-Actin: beta-Actin. PcGAPDH: Glyceraldehyde 3-phosphate dehydrogenase. The two letters Pc stands for Procambarus clarkii.

\begin{tabular}{|c|c|c|}
\hline Primer ID & Forward $5^{\prime}-3^{\prime}$ & Reverse $5^{\prime}-3^{\prime}$ \\
\hline PcVTG1 & TCACCAGTCAACAGAGCAGC & TTCTCAGCACACCGAACTGC \\
\hline PcVTG2 & GAGGGTGGAAAGTCAGCTCC & ACAGTTCATCGCTCCTTCGG \\
\hline PcVTG3 & GTCGGACTGCAGATGAAGGG & AACAAAGCCTTCGGTTTGCG \\
\hline PcVTG4 & TCTGTTGAGAAAGCCGAGCC & TCTAGGCGTACTAGACCCAGC \\
\hline PcBGBP1 & CACACAAGACGAAGTGCTGC & TAAACGGTGCTAAGGGCTGG \\
\hline PcBGBP2 & ССССТAGCATTAGCAACCCC & ACAACTCGGCGTCTTTCTCG \\
\hline PcEF1 $\alpha$ & AGATCTGAAACGTGGTTTTGTT & TCAATCTTTTCCAGAAGTTCGT \\
\hline Pc $\beta$-Actin & AGGGCGTGATGGTTGGTAT & CCGTGCTCAATGGGATATTT \\
\hline PcGAPDH & СТCСATCTTTGACGCTAAGGC & GCACTATCCACCTTCTGCATG \\
\hline
\end{tabular}


Primer efficiencies were calculated using LinReg v.12.18 [49] for all primer sets used. As putative housekeeping genes, Elongation factor 1 alpha $(E F 1 \alpha), \beta$-Actin and Glyceraldehyde 3-phosphate dehydrogenase $(G A P D H)$ were tested by qRT-PCR following the same thermal cycle profile as the target transcripts. Their expression in all the experimental samples was evaluated using the BestKeeper [50], NormFinder [51] and geNorm [52] software to select at least the two most suitable and stable reference genes. Expression values of all examined transcripts for each experimental group and gene expression analysis were performed using Bio Rad CFX Manager v. 3.1 software.

\section{Results}

\subsection{Characterization of VTG-like Transcripts}

The full length VTG of Cherax quadricarinatus (GenBank identifier AAG17936; [19]) was used as initial reference to characterize the identified VTGs from the P. clarkii ATLAS transcriptome library. This reference sequence is 7944 nucleotides long and encodes for a protein of 2584 aa. Four domains were found by CDD [53] at NCBI: a vitellogenin_N domain (pfam 01347) in the interval 42-585 aa, a domain of unknown function (DUF1943, pfam09172) in the range 617-918 aa, a von Willebrand factor type D domain (2345-2491 aa) and a C8 domain (pfam08742) in the range 2530-2576 aa.

The four identified VTGs from P. clarkii (Figure S1) had an open reading frame length between $6024 \mathrm{bp}$ (VTG3) and $8361 \mathrm{bp}$ (VTG1) encoding for proteins ranging from 2007 to 2777 aa (Figure 1A), while the two identified BGBPs ranged for proteins of 4234 aa and 4806 aa (Figure $1 B)$.

All the transcripts contained both a Vitellogenin_N super family and DUF1943 domains and various domains such as von Willebrand factor, type D domain shared among VTG from C. quadricarinatus, VTG1, VTG4 and BGBP2 from P. clarkii or C8 domain present in VTG from C. quadricarinatus and BGBP2.

The VTG1 (GenBank ID OK142726) in P. clarkii consisted of an open reading frame of $8361 \mathrm{bp}$ and a deduced protein of 2777 amino acids with a predicted molecular weight (MW) of $315 \mathrm{kDa}$. It has a putative cleavage site between position 19 and 20: VRA-AP (probability: 0.93) indicating the secretory nature of the molecule. The domains alongside their positions on the transcripts are indicated in Figure 1.

The VTG2 (GenBank ID OK142727) consisted of an open reading frame of $6075 \mathrm{bp}$ encoding for a protein of 2024 aa with a predicted MW of $270 \mathrm{KDa}$. A cleavage site was identified between position 18 and 19: ARA-AP (probability: 0.90).

The VTG3 (GenBank ID OK142728) consisted of an open reading frame of $6024 \mathrm{bp}$ encoding for a protein of 2007 aa with an estimated MW of $223 \mathrm{KDa}$. The cleavage site was identified between position 18 and 19: ARA-AP (probability: 0.90).

The VTG4 (GenBank ID OK142729) consisted of an open reading frame of $7746 \mathrm{bp}$ encoding for a peptide of 2571 aa (MW $289 \mathrm{KDa}$ ). A cleavage site was present between aa in position 18 and 19: ARA-AP (probability: 0.90).

The VTG1 resulted the longest transcript followed by VTG4, whereas VTG2, and 3 had roughly the same length (Figure S2).

The high-density lipoprotein / $\beta$ glucan binding protein $(B G B P)$ is a pattern recognition protein responsible for the transport of lipids which is also fundamental for the innate immune response of crustaceans $[40,41]$.

The BGBP1 (GenBank ID OK142730) and the BGBP2 (GenBank ID OK142731) were found to be longer than VTGs with 14,661 bp (encoding for a protein of 4886 aa) and 12,705 bp (protein of 4234 aa), respectively. DUF 1943 domain is the only domain shared with the VTGs and a VWF domain, type D is shared between VTG1 and BGBP2.

Phylogenetic inference (Figure 2) suggests that all vitellogenins descend from two lineages that hold Cladocera, Isopoda and Copepoda together (cluster in light grey in Figure 2) and Decapoda apart (cluster in dark grey in Figure 2). As expected, all VTGs found in P. clarkii belonged to the Decapoda lineage and formed a cluster with the VTG of C. quadricarinatus and $H$. americanus. 
A

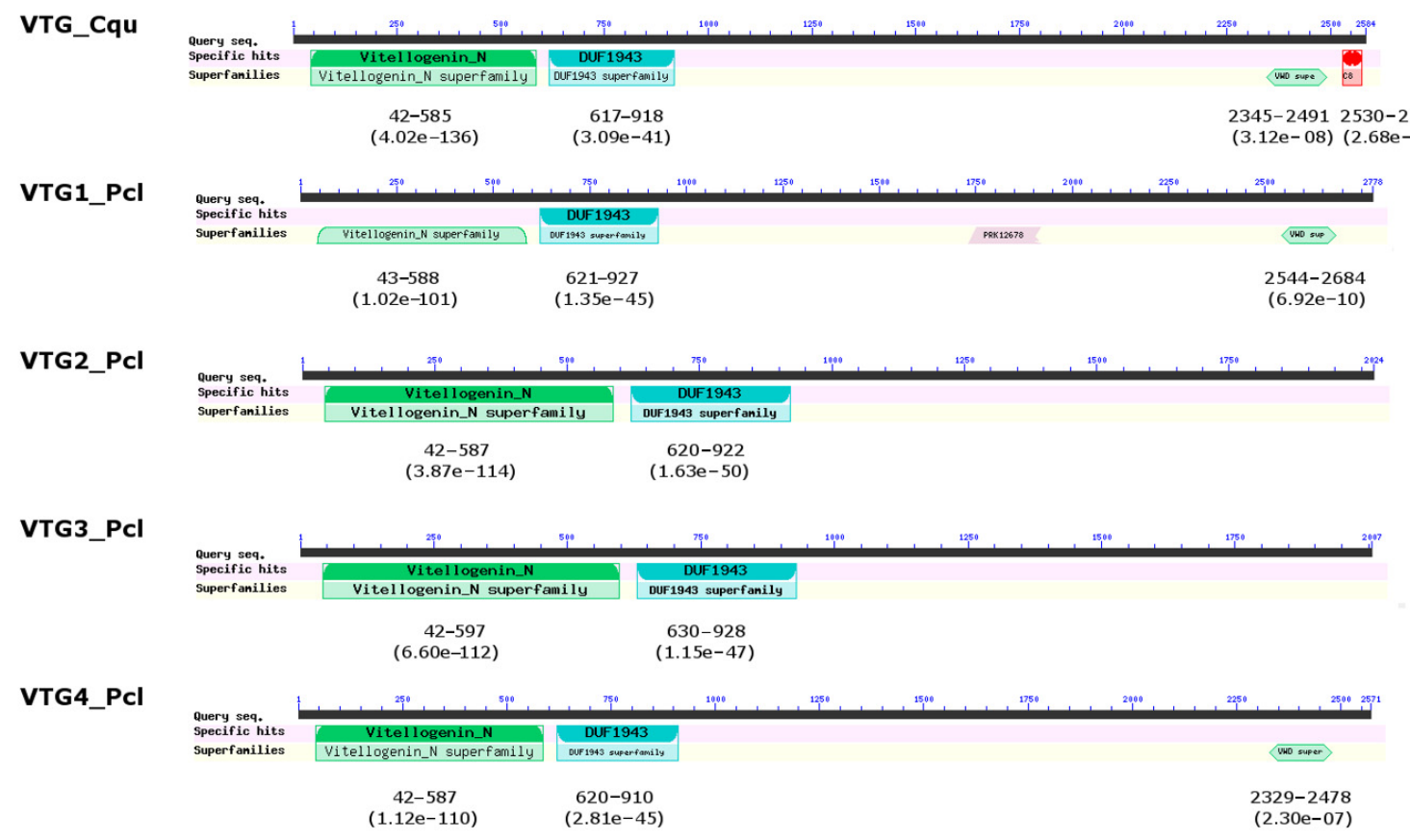

\section{B}

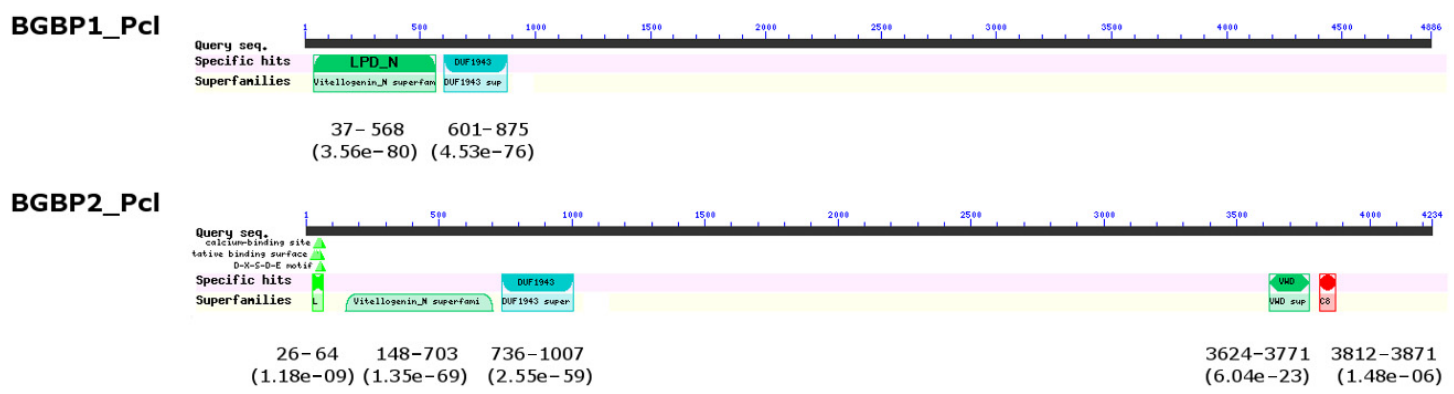

Figure 1. (A) Protein structure of VTGs and BGBPs from P. clarkii (Pcl) along with the VTG used as reference from C. quadricarinatus (Cqu). Domains are shown alongside their position in each protein and between brackets is reported the E-value obtained in CDD (NCBI). (B) Protein structure of BGBPs from P. clarkii.

\subsection{Expression of VTG-Like Transcripts during Ovarian Development}

The expression pattern of the 4 VTGs and the 2 BGBPs in the ovary and in the hepatopancreas of twenty P. clarkii females expressing all stages of oocyte development from stage 2 to 6 (Figure 3) was investigated. The oocyte development staging followed Alcorlo et al. [46] criteria and the expression level was evaluated by qRT-PCR.

Figure 4 shows the different $V T G$ s and BGBPs expression profiles at the diverse ovarian stages. Three different gene expression patterns have been observed. The first one is characteristic of the VTG1 with a gradual increase of its expression from ovarian development stage 4 exclusively in the ovary. The second one is characteristic of VTG2-4, with a marked expression in the hepatopancreas only at ovarian development stage 6 . The third one concerns $B G B P 1-2$, whose expression appears to be homogeneous and stable among all ovarian stages, but only in the hepatopancreas tissue. 


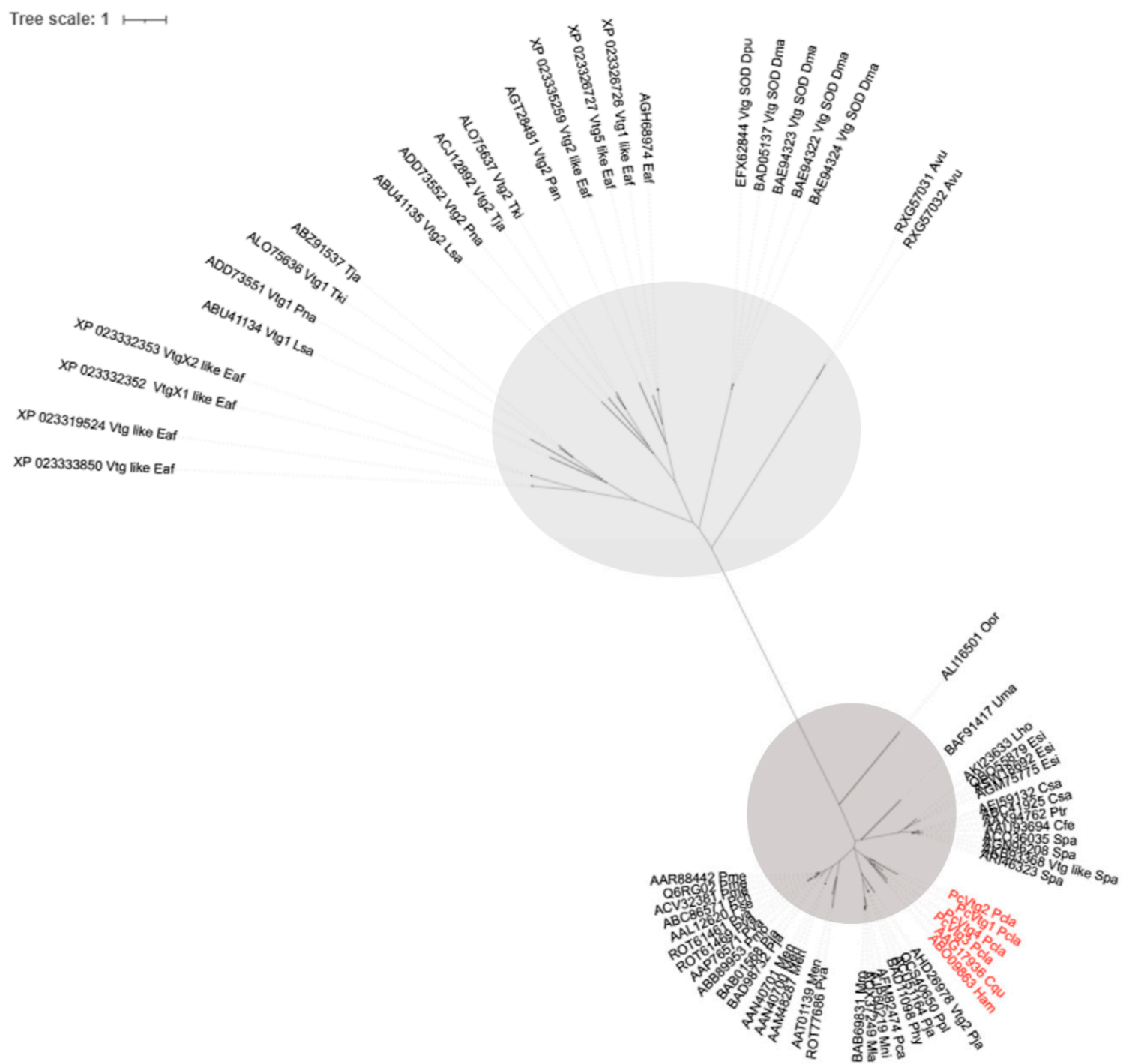

Figure 2. PhylML tree of complete VTGs stored in GenBank (until 4 July 2021). Each sequence is labelled with the corresponding GenBank ID followed by a three-character code: the first letter represents the genus name and the other two the species. P. clarkii VTGs characterized in the present study are indicated in red. In light grey is selected the cluster of Cladocera, Isopoda and Copepoda, while in dark grey the cluster of Decapoda.

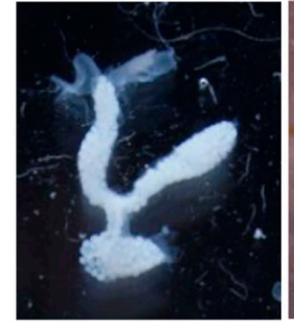

STAGE 2

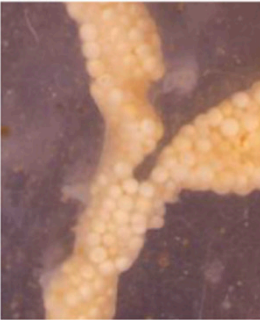

STAGE 3

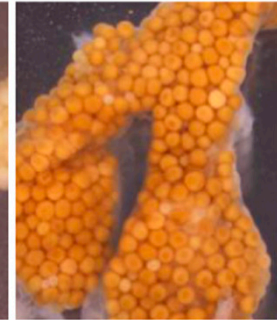

STAGE 4

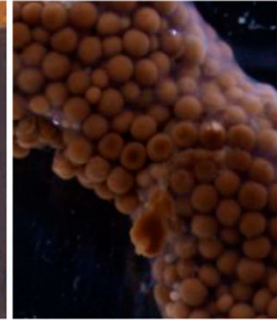

STAGE 5

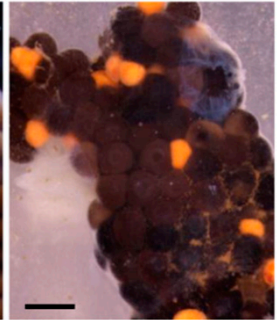

STAGE 6

Figure 3. Appearance and coloration of the ovaries of $P$. clarkii in relation to their stage of maturity. The ovaries at different stages are shown at the same magnification. Stage 2 represents immature oocytes until stage 6, when the ovary is fully mature and active. Scale bar $2.5 \mathrm{~mm}$. 

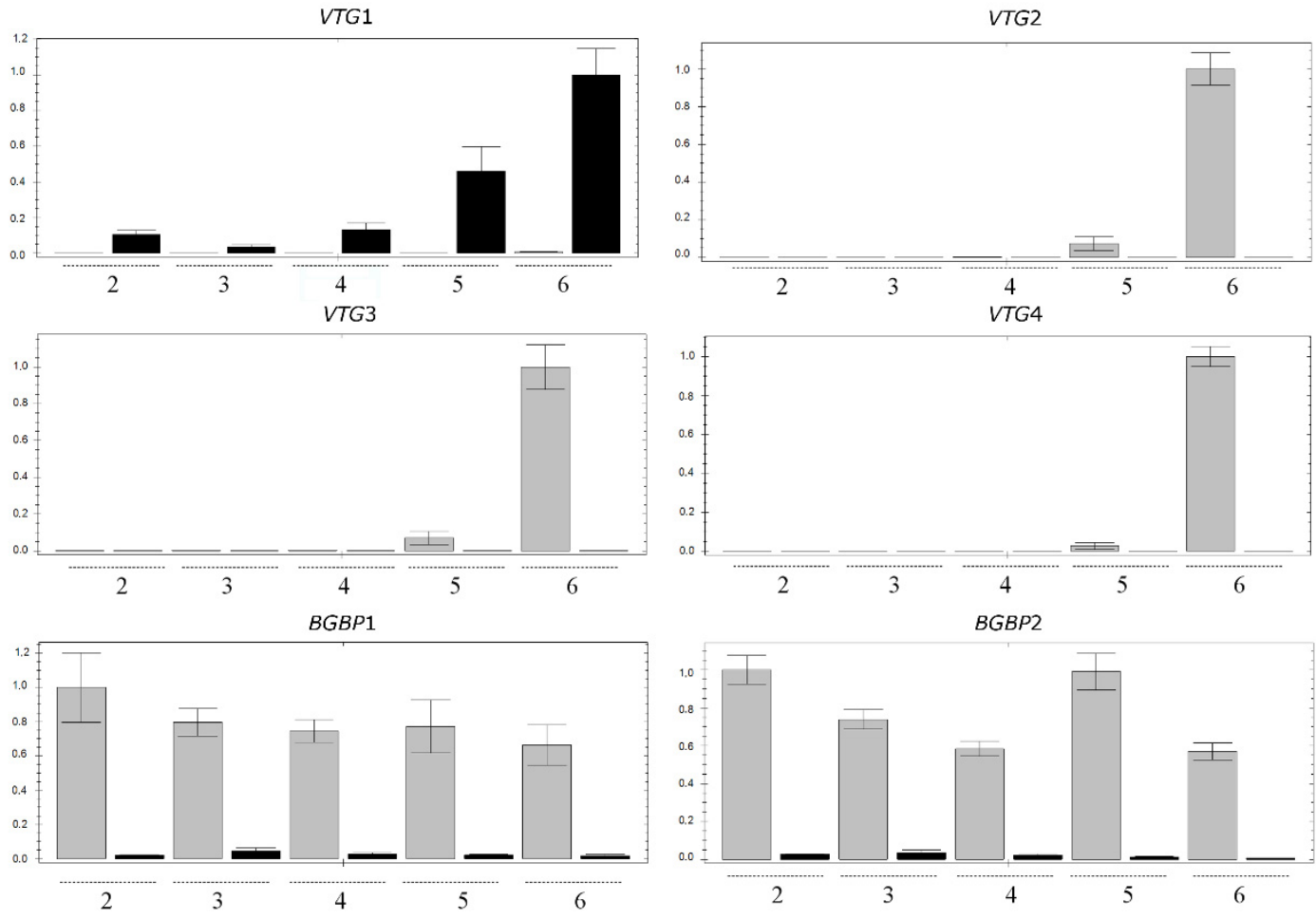

Figure 4. Relative VTGs and BGBPs expressions in P. clarkii during ovarian development assessed through qRT-PCR, using $G A P D H$ and $E F 1 \alpha$ as reference genes. Results are mean $\pm \mathrm{SD}$ of three technical replicates. The $y$ axis of each graph is scaled based on the highest level of expression and indicates the relative expression of each target transcript. Dark bars represent the ovary and grey bars the hepatopancreas tissues; $2,3,4,5$, and 6 are the ovary developmental stages.

\section{Discussion}

The study investigated the number of VTGs orthologs present in the red swamp crayfish P. clarkii, since up to two VTGs were found in previous studies [19-29]. From the ATLAS library derived from the sequencing of 12 different tissues, four VTGs and two BGBP (VTG-like) transcripts were assembled and mapped (Figure 1), and this novel phenomenon was probably the result of multiplicity of VTG genes and/or alternative spliced forms.

The full length of the single VTG cDNA in crustaceans is about 8 kilobases $(\mathrm{kb})$ in size and encodes 2500-2600 amino acid residues. The VTG sizes identified in P. clarkii are in line with the work by Avarre and colleagues [54].

To validate the bioinformatic results, phylogenetic analyses on all the complete VTGs available at present from public repositories were analyzed, identifying a separation between Decapoda and a group clustering Copepoda, Isopoda and Cladocera (Figure 2). The presence of an N-terminal lipid binding domain and a DUF 1943 domain suggests the relationship with the large lipid transfer proteins [41]. Two putative dibasic furin cleavage sites (with the motifs RAKR and RARR, respectively) were identified bordering the sequence of the BGBP. A similar protein with identical domain architecture was found in the prawn Macrobrachium rosenbergii suggesting a conserved structure among crustacean species [41].

The present study was aimed at two additional aspects of the vitellogenesis, the differential contribution of the hepatopancreas and the ovary in the process and the relationships of the $d L p / H D L-B G B P$ protein to the vitellogenic process in view of its mutual domains with the VTG and its role as lipid carrier. The $d L p / H D L-B G B P$ was found to not to be affected by ovarian development regulation pathways, hence not specifically contributing to ovarian development. Its expression in both organs is constitutive, higher in the hepatopancreas in 
comparison to the ovary. This high hepatopancreatic expression may be generally required to carry lipid products from this metabolic organ to other tissues.

The major novel finding of this work is the multiplicity of VTG transcripts in P. clarkii above the previously recognized two genes, and their organ-specific transcription in the ovary or the hepatopancreas with different expression scheduling. It starts in the ovary at stage $4 / 5$ in which the ovary quickly enlarges and accumulates reserve materials. The hepatopancreas contributes to VTG production only at stage 6 probably to reinforce VTG production and boost maturation (Figure 4). These results support the idea that multiple VTGs are involved in ovarian maturation and that the contribution comes from both the hepatopancreas and the ovary, especially at stage 6 (complete ovarian maturation) in red swamp crayfish. Monitoring the four VTGs identified here could expand studies of reproduction in this species and shed light on potential methods that interfere ovarian maturation to develop new methods to contrast the spread of P. clarkii. Conversely, an in-depth analysis of the expression of VTGs could also be useful for aquaculture. It may be suggested that the ovary is the primary site of VTG production, required by the oocytes located in the ovary. However, the need for fast development of bigger ova led to the evolutionary need for an external reinforcement of the production by the major crustacean metabolic organ, the hepatopancreas. Only one VTG is expressed in the ovary, VTG1, while the others (VTG2-4) are expressed only in the hepatopancreas (Figure 4).

Cambarid crayfish complete their larval development within the ova and consequently have relatively large ova containing sufficient amounts of reserve materials to complete the development without external feeding. Future studies may focus on the full sequencing of all involved genes, attempting at the elucidation of mutual or different regulatory upstream sequences which may explain the different transcription patterns.

Supplementary Materials: The following figures are available online at https:/ /www.mdpi.com/ article/10.3390/d13090445/s1, Figure S1: Tracks of each reconstructed VTGs and lipid carriers, Figure S2: Schematic alignment of the 4 VTGs retrieved from the ATLAS of P. clarkii.

Author Contributions: Conceptualization, C.M., M.T., M.A., S.B., A.P. and P.G.G.; methodology, C.M. and M.T.; software, C.M. and M.T.; validation, C.M. and M.T.; formal analysis, C.M. and M.T.; resources, A.P. and P.G.G.; data curation, C.M., A.P. and P.G.G.; writing-original draft preparation, C.M. and M.T.; writing-review and editing, C.M., M.T., M.A., S.B., A.P. and P.G.G.; visualization, C.M., and P.G.G.; supervision, P.G.G.; All authors have read and agreed to the published version of the manuscript.

Funding: This research received no external funding.

Institutional Review Board Statement: Not applicable.

Data Availability Statement: The data presented in this study, in particular the sequences of the identified 4 VTGs and 2 BGPBs are openly available in GenBank.

Acknowledgments: We thank Luca Peruzza and Federica Piazza for their contribution in collecting the crayfish specimens and Marco Gerdol and Samuele Greco for bioinformatics support.

Conflicts of Interest: The authors declare no conflict of interest. The funders had no role in the design of the study; in the collection, analyses, or interpretation of data; in the writing of the manuscript, or in the decision to publish the results.

\section{References}

1. Busson-Mabillot, S. Données récentes sur la vitellogenèse. Ann. Biol. 1969, 8, 199-228.

2. Dhainaut, A.; De Leersnyder, M. Etude cytochimique et ultrastructurale de l'évolution ovocytaire du crabe Eriocheir sinensis. I. Ovogenèse naturelle. Arch. Biol. 1976, 87, 261-282.

3. Meusy, J.J. Vitellogenin, the extraovarian precursor of the protein yolk in Crustacea: A review. Reprod. Nutr. Dévelop. 1980, 20, 1-21. [CrossRef] [PubMed]

4. Kerr, M.S. The hemolymph proteins of the blue crab, Callinectes sapidus. II. A lipoprotein serologically identical to oocyte lipovitellin. Develop. Biol. 1969, 20,1-17. [CrossRef] 
5. Lee, C.Y.; Watson, D. In Vitro study of vitellogenesis in the blue crab (Callinectes sapidus): Site and control of vitellin synthesis. J. Exp. Zool. 1995, 271, 364-372. [CrossRef]

6. Browdy, C.L.; Fainzilber, M.; Tom, M.; Loya, Y.; Lubzens, E. Vitellin synthesis in relation to oogenesis in vitro incubated ovaries of Penaeus semisulcatus. J. Exp. Zool. 1990, 255, 205-215. [CrossRef]

7. Mak, A.S.; Choi, C.L.; Tiu, S.H.; Hui, J.H.; He, J.G.; Tobe, S.S.; Chan, S.M. Vitellogenesis in the red crab Charybdis feriatus: Hepatopancreas-specific expression and farnesoic acid stimulation of vitellogenin gene expression. Mol. Reprod. Dev. 2005, 70, 288-300. [CrossRef]

8. Yang, W.J.; Ohira, T.; Tsutsui, N.; Subramoniam, T.; Huong, D.T.T.; Aida, K.; Wilder, M.N. Determination of amino acid sequence and site of mRNA expression of four vitellins in the giant freshwater prawn, Macrobrachium rosenbergii. J. Exp. Zool. 2000, 287, 413-422. [CrossRef]

9. Girish, B.P.; Swetha, C.; Reddy, P.S. Hepatopancreas but not ovary is the site of vitellogenin synthesis in female fresh water crab, Oziothelphusa senex. Biochem. Biophy. Res. Commun. 2014, 447, 323-327. [CrossRef]

10. Tsutsui, N.; Saido-Sakanaka, H.; Yang, W.J.; Jayasankar, V.; Jasmani, S.; Okuno, A.; Ohira, T.; Okumura, T.; Aida, K.; Wilder, M.N. Molecular characterization of a cDNA encoding vitellogenin in the coonstriped shrimp, Pandalus hypsinotus and site of vitellogenin mRNA expression. J. Exp. Zool. 2004, 301, 802-814. [CrossRef]

11. Ding, X.; Nagaraju, G.P.C.; Novotney, D.; Lovett, D.L.; Borst, D.W. Yolk protein expression in the green crab, Carcinus maenas. Aquaculture 2010, 298, 325-331. [CrossRef]

12. Li, K.; Chen, L.; Zhou, Z.; Li, E.; Zhao, X.; Guo, H. The site of vitellogenin synthesis in Chinese mitten-handed crab Eriocheir sinensis. Comp. Biochem. Physiol. B 2006, 143, 453-458. [CrossRef]

13. Bai, H.; Qiao, H.; Li, F.; Fu, H.; Sun, S.; Zhang, W.; Jin, S.; Gong, Y.; Jiang, S.; Xiong, Y. Molecular characterization and developmental expression of vitellogenin in the oriental river prawn Macrobrachium nipponense and the effects of RNA interference and eyestalk ablation on ovarian maturation. Gene 2015, 562, 22-31. [CrossRef]

14. Okumura, T.; Yamano, K.; Sakiyama, K. Vitellogenin gene expression and hemolymph vitellogenin during vitellogenesis, final maturation, and oviposition in female kuruma prawn, Marsupenaeus japonicus. Comp. Biochem. Physiol. A 2007, 147, 1028-1037. [CrossRef]

15. Hiransuchalert, R.; Thamniemdee, N.; Khamnamtong, B.; Yamano, K.; Klinbunga, S. Expression profiles and localization of vitellogenin mRNA and protein during ovarian development of the giant tiger shrimp Penaeus monodon. Aquaculture 2013, 412-413, 193-201. [CrossRef]

16. Jia, X.; Chen, Y.; Zou, Z.; Lin, P.; Wang, Y.; Zhang, Z. Characterization and expression profile of Vitellogenin gene from Scylla paramamosain. Gene 2013, 520, 119-130. [CrossRef]

17. Salmela, H.; Stark, T.; Stucki, D.; Fuchs, S.; Freitak, D.; Dey, A.; Kent, C.F.; Zayed, A.; Dhaygude, K.; Hokkanen, H.; et al. Ancient Duplications Have Led to Functional Divergence of Vitellogenin-Like Genes Potentially Involved in Inflammation and Oxidative Stress in Honey Bees. Genome Biol. Evol. 2016, 8, 495-506. [CrossRef]

18. Wurm, Y.; Wang, J.; Riba-Grognuz, O.; Corona, M.; Nygaard, S.; Hunt, B.G.; Ingram, K.K.; Falquet, L.; Nipitwattanaphon, M.; Gotzek, D.; et al. The genome of the fire ant Solenopsis invicta. Proc. Natl. Acad. Sci. USA 2011, 108, 5679-5684. [CrossRef]

19. Abdu, U.; Davis, C.; Khalaila, I.; Sagi, A. The vitellogenin cDNA of Cherax quadricarinatus encodes a lipoprotein with calcium binding ability, and its expression is induced following the removal of the androgenic gland in a sexually plastic system. Gen. Comp. Endocrinol. 2002, 127, 263-272. [CrossRef]

20. Avarre, J.-C.; Michelis, R.; Tietz, A.; Lubzens, E. Relationship between vitellogenin and vitellin in a marine shrimp (Penaeus semisulcatus) and molecular characterization of vitellogenin complementary DNAs. Biol. Reprod. 2003, 69, 355-364. [CrossRef]

21. Okuno, A.; Yang, W.J.; Jayasankar, V.; Saido-Sakanaka, H.; Huong, D.T.T.; Jasmani, S.; Atmomarsono, M.; Subramoniam, T.; Tsutsui, N.; Ohira, T.; et al. Deduced Primary Structure of Vitellogenin in the Giant Freshwater Prawn, Macrobrachium rosenbergii, and Yolk Processing During Ovarian Maturation. J. Exp. Zool. 2002, 292, 417-429. [CrossRef]

22. Jeon, J.M.; Lee, S.O.; Kim, K.S.; Baek, H.J.; Kim, S.; Kim, I.K.; Mykles, D.L.; Kim, H.W. Characterization of two vitellogenin cDNAs from a Pandalus shrimp (Pandalopsis japonica): Expression in hepatopancreas is down-regulated by endosulfan exposure. Comp Biochem. Physiol. B 2010, 157, 102-112. [CrossRef]

23. Phiriyangkul, P.; Utarabhand, P. Molecular Characterization of a cDNA Encoding vitellogenin in the banana shrimp, Penaeus (Litopenaeus) merguiensis and sites of vitellogenin mRNA Expression. Molec. Reprod. Dev. 2006, 73, 410-423. [CrossRef]

24. Raviv, S.; Parnes, S.; Segall, C.; Davis, C.; Sagi, A. Complete sequence of Litopenaeus vannamei (Crustacea: Decapoda) vitellogenin cDNA and its expression in endocrinologically induced sub-adult females. Gen. Comp. Endocrinol. 2006, 145, 39-50. [CrossRef] [PubMed]

25. Tiu, S.H.K.; Hui, J.H.L.; Mak, A.S.C.; He, J.G.; Chan, S.M. Equal contribution of hepatopancreas and ovary to the production of vitellogenin (PmVg1) transcripts in the tiger shrimp, Penaeus monodon. Aquaculture 2006, 254, 666-674. [CrossRef]

26. Tsang, W.S.; Quackenbush, S.L.; Chow, B.K.C.; Tiu, S.H.K.; He, J.G.; Chan, S.M. Organization of the shrimp vitellogenin gene: Evidence of multiple genes and tissue specific expression by the ovary and hepatopancreas. Gene 2003, 303, 99-109. [CrossRef]

27. Tsutsui, N.; Kawazoe, I.; Ohira, T.; Jasmani, S.; Yang, W.J.; Wilder, M.N.; Aida, K. Molecular characterization of a cDNA encoding vitellogenin and its expression in the hepatopancreas and ovary during vitellogenesis in the kuruma prawn, Penaeus japonicus. Zool. Sci. 2000, 17, 651-660. [CrossRef] [PubMed] 
28. Xie, S.; Sun, L.; Liu, F.; Dong, B. Molecular characterization and mRNA transcript profile of vitellogenin in Chinese shrimp, Fenneropenaeus chinensis. Molec. Biol. Rep. 2009, 36, 389-397. [CrossRef]

29. Yang, F.; Xu, H.T.; Dai, Z.M.; Yang, W.J. Molecular characterization and expression analysis of vitellogenin in the marine crab Portunus trituberculatus. Comp. Biochem. Physiol. B 2005, 142, 456-464. [CrossRef] [PubMed]

30. Wang, Q.; Cheng, L.; Liu, J.; Li, Z.; Xie, S.; Silva, S.S.D. Freshwater aquaculture in PR China: Trends and prospects. Rev. Aquac. 2015, 7, 283-302. [CrossRef]

31. Putra, M.D.; Bláha, M.; Wardiatno, Y.; Krisanti, M.; Yonvitner; Jerikho, R.; Kamal, M.M.; Mojžišová, M.; Bystřický, P.K.; Kouba, A.; et al. Procambarus clarkii (Girard, 1852) and crayfish plague as new threats for biodiversity in Indonesia. Aquat. Conserv. 2018, 28, 1434-1440. [CrossRef]

32. Haubrock, P.J.; Oficialdegui, F.J.; Zeng, Y.; Patoka, J.; Yeo, D.C.J.; Kouba, A. The red claw crayfish: A prominent aquaculture species with invasive potential in tropical and subtropical biodiversity hotspots. Rev. Aquac. 2021, 13, 1488-1530. [CrossRef]

33. Gherardi, F.; Barbaresi, S.; Salvi, G. Spatial and temporal patterns in the movement of Procambarus clarkii, an invasive crayfish. Aquat. Sci. 2000, 62, 179-193. [CrossRef]

34. Scalici, M.; Gherardi, F. Structure and dynamics of an invasive population of the red swamp crayfish (Procambarus clarkii) in a Mediterranean wetland. Hydrobiologia 2007, 583, 309-319. [CrossRef]

35. Peruzza, L.; Piazza, F.; Manfrin, C.; Bonzi, L.C.; Battistella, S.; Giulianini, P.G. Reproductive plasticity of a Procambarus clarkii population living $10^{\circ} \mathrm{C}$ below its thermal optimum. Aquat. Inv. 2015, 10, 199-208. [CrossRef]

36. Silveyra, G.R.; Silveyra, P.; Vatnick, I.; Medesani, D.A.; Rodríguez, E.M. Effects of atrazine on vitellogenesis, steroid levels and lipid peroxidation, in female red swamp crayfish Procambarus clarkii. Aquat. Toxicol. 2018, 197, 136-142. [CrossRef]

37. Guan, Z.B.; Yin, J.; Chen, K.; Shui, Y.; Cai, Y.J.; Liao, X.R. The hepatopancreas and ovary are the sites of vitellogenin synthesis in female red swamp crayfish Procambarus clarkii (Girard, 1852) (Decapoda: Astacoidea: Cambaridae). J. Crust. Biol. 2016, 36, 637-641. [CrossRef]

38. Kang, P.F.; Mao, B.; Fan, C.; Wang, Y.F. Transcriptomic information from the ovaries of red swamp crayfish (Procambarus clarkii) provides new insights into development of ovaries and embryos. Aquaculture 2019, 505, 333-343. [CrossRef]

39. Zhong, Y.; Zhao, W.; Tang, Z.; Huang, L.; Zhu, X.; Liang, X.; Yan, A.; Lu, Z.; Yu, Y.; Tang, D.; et al. Comparative transcriptomic analysis of the different developmental stages of ovary in red swamp crayfish Procambarus clarkii. BMC Genom. 2021, 22, 199. [CrossRef]

40. Duvic, B.; Söderhäll, K. Purification and partial characterization of a beta-1,3-glucanbinding-protein membrane receptor from blood cells of the crayfish Pacifastacus leniusculus. Eur. J. Biochem. 1992, 207, 223-228. [CrossRef]

41. Stieb, S.; Roth, Z.; Dal Magro, C.; Fischer, S.; Butz, E.; Sagi, A.; Khalaila, I.; Lieb, B.; Schenk, S.; Hoeger, U. One precursor, three apolipoproteins: The relationship between two crustacean lipoproteins, the large discoidal lipoprotein and the high density lipoprotein/ $\beta$-glucan binding protein. Biochim. Biophys. Acta 2014, 1841, 1700-1708. [CrossRef]

42. Lemoine, F.; Correia, D.; Lefort, V.; Doppelt-Azeroual, O.; Mareuil, F.; Cohen-Boulakia, S.; Gascuel, O. NGPhylogeny.fr: New generation phylogenetic services for non-specialists. Nucleic Acids Res. 2019, 47, 260-265. [CrossRef]

43. Katoh, K.; Standley, D.M. MAFFT Multiple Sequence Alignment Software Version 7: Improvements in Performance and Usability. Mol. Biol. Evol. 2013, 30, 772-780. [CrossRef]

44. Criscuolo, A.; Gribaldo, S. BMGE (Block Mapping and Gathering with Entropy): A new software for selection of phylogenetic informative regions from multiple sequence alignments. BMC Evol. Biol. 2010, 10, 210. [CrossRef] [PubMed]

45. Guindon, S.; Dufayard, J.F.; Lefort, V.; Anisimova, M.; Hordijk, W.; Gascuel, O. New Algorithms and Methods to Estimate Maximum-Likelihood Phylogenies: Assessing the Performance of PhyML 3.0. Syst. Biol. 2010, 59, 307-321. [CrossRef] [PubMed]

46. Alcorlo, P.; Geiger, W.; Otero, M. Reproductive biology and life cycle of the invasive crayfish Procambarus clarkii (Crustacea: Decapoda) in diverse aquatic habitats of South-Western Spain: Implications for population. Fundam. Appl. Limnol. 2008, 173, 197-212. [CrossRef]

47. Untergasser, A.; Cutcutache, I.; Koressaar, T.; Ye, J.; Faircloth, B.C.; Remm, M.; Rozen, S.G. Primer3-new capabilities and interfaces. Nucleic Acids Res. 2012, 40, e115. [CrossRef]

48. Ruijter, J.M.; Ramakers, C.; Hoogaars, W.M.; Karlen, Y.; Bakker, O.; van den Hoff, M.J.; Moorman, A.F. Amplification efficiency: Linking baseline and bias in the analysis of quantitative PCR data. Nucleic Acids Res. 2009, 37, e45. [CrossRef]

49. Kibbe, W.A. OligoCalc: An online oligonucleotide properties calculator. Nucleic Acids Res. 2007, 35, 43-46. [CrossRef]

50. Pfaffl, M.W.; Tichopad, A.; Prgomet, C.; Neuvians, T.P. Determination of stable housekeeping genes, differentially regulated target genes and sample integrity: BestKeeper-Excel-based tool using pairwise correlations. Biotech. Lett. 2004, 26, 509-515. [CrossRef]

51. Andersen, C.L.; Jensen, J.L.; Ørntoft, T.F. Normalization of real-time quantitative reverse transcription-PCR data: A model-based variance estimation approach to identify genes suited for normalization, applied to bladder and colon cancer data set. Cancer Res. 2004, 64, 5245-5250. [CrossRef]

52. Vandesompele, J.; De Preter, K.; Pattyn, F.; Poppe, B.; Van Roy, N.; De Paepe, A.; Speleman, F. Accurate normalization of real-time quantitative RT-PCR data by geometric averaging of multiple internal control genes. Genome Biol. 2002, 3, research0034.1. [CrossRef] [PubMed] 
53. Marchler-Bauer, A.; Bryant, S.H. CD-Search: Protein domain annotations on the fly. Nucl. Acids Res. 2004, 32, 327-331. [CrossRef] [PubMed]

54. Avarre, J.C.; Lubzens, E.; Babin, P.J. Apolipocrustacein, formerly vitellogenin, is the major egg yolk precursor protein in decapod crustaceans and is homologous to insect apolipophorin II/I and vertebrate apolipoprotein B. BMC Evol. Biol. 2007, 7, 3. [CrossRef] [PubMed] 